YOSHIMURA ET AL.: DIMORPHISM IN MALE SALMON

\title{
Breeding Games and Dimorphism in Male Salmon
}

Yumi Tanaka ${ }^{1}$, Taro Hayashi ${ }^{2}$, Donald G. Miller III $^{3}$, Kei-ichi Tainaka ${ }^{2}$ and Jin Yoshimura ${ }^{2,4,, \#}$

${ }^{1}$ School of Human Science and Environment, University of Hyogo

${ }^{2}$ Department of Systems Engineering, Shizuoka University

${ }^{3}$ Department of Biological Sciences, California State University, Chico

${ }^{4}$ Department of Environmental and Forest Biology, State University of New York College of

Environmental Science and Forestry

${ }^{5}$ Marine Biosystems Research Center, Chiba University

\#Jin Yoshimura (Shizuoka University, 3-5-1 Johoku, Naka-ku, Hamamatsu 432-8561, Japan :

jin@sys.eng.shizuoka.ac.jp)

Others : Yumi Tanaka (University of Hyogo, 1-1-12 Shinzaike-honcho, Himeji 670-0092,

Japan : e-mail: nd08x012@stshse.u-hyogo.ac.jp)

Taro Hayashi and Kei-ichi Tainaka (Shizuoka University, 3-5-1 Johoku, Naka-ku, Hamamatsu,

432-8561, Japan : sixminus1@gmail.com and tainaka@sys.eng.shizuoka.ac.jp)

Donald G. Miller (California State University, Chico; Chico, CA 95929:

dgmiller@,csuchico.edu)

Breeding Games and Dimorphism in Male Salmon 
YOSHIMURA ET AL.: DIMORPHISM IN MALE SALMON

Jin Yoshimura ${ }^{1,2,3}$, Taro Hayashi ${ }^{+}$, Donald G. Miller $\mathrm{II}^{4}$, Kei-ichi Tainaka ${ }^{+}$and Yumi Tanaka ${ }^{5, \#}$

${ }^{1}$ Department of Systems Engineering, Shizuoka University

${ }^{2}$ Department of Environmental and Forest Biology, College of Environmental Science and

Forestry

${ }^{3}$ Marine Biosystems Research Center, Chiba University

${ }^{4}$ Department of Biological Sciences, California State University, Chice

${ }^{5}$ School of Human Seience and Environment, University of Hyogo

\#Corresponding author: Yumi Tanaka (University of Hyogo, 1-1-12 Shinzaike-honcho, Himeji670-0092, Japan : e-mail: nd08x012@stshse.u-hyogo.ac.jp)

Others : Jin Yoshimura, Taro Hayashi and Kei-ichi Tainaka (Shizuoka University, 3-5-1

書式変更：英語（米国） 
In certain species of salmon, male phenotypes occur in two distinct morphs: the large

"hooknose” (H) or the small “jack” (J). Hooknoses fight each other for access to females, while jacks occupy refuges near spawning beds to sneak fertilizations.into the breeding

bed of a pair. Jacks also fight each other over opportunities for sneaking without immediate gains. To explore whether the jack behavioural strategy is equally adaptive to that of the hooknose, we built a game-theoretic model similar to the classic hawk-dove game, with and without conditions of density dependence. Our model We-demonstrates fitness of the jack strategy increases with the frequency of the hooknose strategy, because jacks can steal the benefits otherwise accrued by hooknoses. The In this game, coexistence of strategies strategy coexistence-is much more easily achieved in this game than in the hawk-dove game. When negative density effects on benefits are introduced to the model, coexistence conditions are further relaxed. Hence, the jack and hooknose strategies can be viewed as equally adaptive, resulting in a stable mixed ESS. When the hooknose-jack game is considered an evolutionary game, frequencies of the two morphs either yield a balanced polymorphism or the fitness function of the hooknose proportion increases. In 
YOSHIMURA ET AL.: DIMORPHISM IN MALE SALMON

Keywords: morph, jJack, hooknose, coexistence, game-theoretic model, fitness, alternative

mating strategy, evolutionarily stable strategy, conditional strategy, hawk-dove game 
YOSHIMURA ET AL.: DIMORPHISM IN MALE SALMON

$\underline{\text { In many animal species, competition among males for mating privileges is prevalent }}$

(Krebs \& Davies 1987). Such rivalries may favour selection for male dimorphism, alternative

mating strategies, or both. The hawk-dove game was developed as a means of understanding the

theoretical basis of animal conflict (Maynard Smith \& Price 1973), and the evolutionary game

of animal fighting in particular (Bulmer 1994). However, it has only rarely been applied to the evolutionary ecology of mating systems.

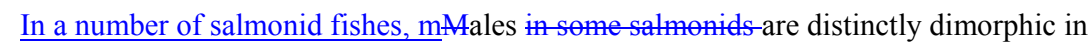
body size, external morphology and life history (Gross 1984, 1985). LA Alarge breeding males called "hooknoses" $(\mathrm{H})$, undergo full development, is a fullyhaving spent matured malespending two tọr three years at sea before returning to theirits natal rivers to spawn with females. Hooknoses develop display courtship colouration and a hooked nose with sharp teeth for fighting. ByIn contrast, a small males, called "jacks" (J), undergo limited development and resembles an immature fish. As juveniles, precocious males become jacks and return to spawning beds at least one year before hooknoses (Gross 1991). Hooknose males battle other hooknoses for access to females. Hower, Jjacks, however, seek refuges neaknear the breeding grounds of a paired fish, from which they sneak to release sperm and swim through the beds releasing sperm-immediately following female spawning. 
YOSHIMURA ET AL.: DIMORPHISM IN MALE SALMON

Hooknose and jack are considered alternative strategies (Gross 1982; Thornhill \& Alcock

1983) or conditional mating strategies (Gross 1996). Gross (1984) considered such alternative-

mating strategies as evolutionarily stable strategies (ESSs) (Maynard Smith 1982), provided the-

payoffs of both $\mathrm{H}$ and $\mathrm{J}$ are equal. If the payoff of $\mathrm{J}$ is smaller than that of $\mathrm{H}$, the jack strategy is

the less fit conditional mating tactic. Gross also found that the lifetime fitnesses of $\mathrm{H}$ and $\mathrm{J}$ in

coho salmon (Oncorhynchus kisutch) are about equal at their switchpoint, indicating the mixed

1985). Thus Gross $(1984,1985)$ suggested that the dimorphism in male salmon might have

evolved through an evolutionary game. However, as far as we know, its explicit its-payoff matrices* $x_{2}$ withas well as and the ESS-conditions for coexistence of alternative strategies, have not been examined explicitly_in the context of a hawk-dove game.

\section{Competition among male animals for mating privileges is very common (Krebs \& Davies-}

1987). Such competition may favor selection for male dimorphism, alternative mating strategies, or both. The hawk-dove game was developed as a means of understanding the theoretical basis
書式変更：フォントの色：赤 
YOSHIMURA ET AL.: DIMORPHISM IN MALE SALMON

of animal conflict (Maynard Smith \& Price 1973), and the evolutionary game of animal fighting in particular (Bulmer 1994). However, it has rarely been applied to the evolutionary ecology of mating systems. understanding of dimorphic male strategies in male orangutans our group showed that maledimorphism in the orangutan could be explained by a version of the hawk dove game-(Tainaka et al. 2007). However, life--history considerations for evolutionary games differ substantially between the orangutan and salmon. In the orangutan, subordinate adult males can switch

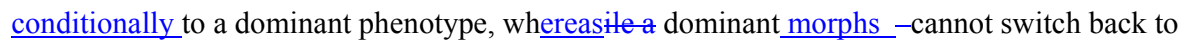
thea subordinate phenotype. In salmon, the choice between developing into a hooknose or a jack reflects early developmental differences in individual life history and is absolutely irreversible

(Gross 1985, 1991). Gross further suggested juvenile body size, a strong predictor of mating strategy, is a function of population density Gross 1991). Published estimates of additive genetic 
YOSHIMURA ET AL.: DIMORPHISM IN MALE SALMON

underlying genetic mechanisms regulating salmon dimorphism may be similar to genetic polymorphisms in the fruit fly (Fitzpatrick et al. 2007) or scale-eating cichlid fish (Hori 1993;

Takahashi \& Hori 1994).

Here we show that male dimorphism in salmon can be explained by a breeding game

similar to the hawk-dove game. We build a payoff matrix for two mating strategies of male

salmon: Hooknose and Jack. We analyze the ESS conditions according to the benefits and costs

of and lose onteringing and losing, including an explicit examination of the effects of

population density. We also discuss the utility and generality of hawk-dove-like games in male

dimorphisms and alternative mating strategies.

\section{HOOKNOSE-JACK MODEL}

Our game model resembles that of the hawk-dove game (Maynard Smith \& Price 1973).

For our purposes, By "hawk vs. dove" is equivalent towe mean "dominant vs. subordinate" or,

more generally, "honest contestanty competitor-vs. cheater." The pay-off matrix for a male 
salmon is given in Table 1. A hooknose $(\mathrm{H})$ fights with others. The winning hooknoseer gets the benefit $V$ (mating value), while the loser suffers the fighting cost $C$. Hence tThe average payoff for a hooknose is $(V-C) / 2$. A hooknose can defeat a jack $(\mathrm{J})$ easily, but a jack can sneak in and spawn surreptitiously. By sneaking fertilizations from hooknoses, a jack obtains So, a jack robsthe benefit $G$ (on the average) by sneaking, while thea hooknose loses $G$, resulting inyielding the payoff $V-G$. Unlike the well-known "dove," which does not fight, a jack battles other jacks over positions advantageous for sneaking. The winning jack gains fitness value $J$. The losing

jack suffers cost $J L$; therefore, the the average jack fighting cost of fighting between jacks is JL/2, since one jack will loses. Because of the great disparity in body size between hooknose-

and jack, we assume that $V>G>0$ and $G>I>L>0$. In reality, both benefits and costs of fighting between hooknoses should be very large and those of jacks should be relatively small, so that $\forall \gg G$, and $G \gg \underline{J} L$.

Unlike the well-known "dove," which does not fight, a jack battles other jacks over positions advantageous for sneaking. The losing jack suffers cost $L$. On the other hand, the winning jack gains control of the refuge from which he can sneak, the sneaking pesitionbut-only without immediate benefits.- For now, we simply assume that the winning jack has no-gains nothing.

Therefore, the average cost to jacks of fighting jack fighting cost-is $L / 2$, since one will lose.

書式変更：フォントの色：赤 書式変更：フォントの色：赤

書式変更：フォントの色：自動 書式変更：フォントの色：自動 
and $C>L>0$. In reality, both benefits and costs of fighting between hooknoses should be very

large and those of jacks should be relatively small, so that $V \gg>G$, and $C>>L$.

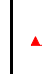

The payoffs in Table 1 differ from those of the classicusual hawk-dove game in all values

except that of $\mathrm{H}$ vs. H. Without considering the population size of male salmon, the Now we

assume a constant population size of male salmon and find the fitness values of both hooknose

and jack can be evaluated by the traditional ESS analysis (that implicitly assumes an infinite

population size) (see Riley 1979; Fogel et al. 1998; Taylor et al. 2004). - - Let $p$ be the proportion

of hooknose in the population. Then the fitness of a hooknose $W_{\mathrm{H}}(p)$ is represented by Equation

(1) (Table 2).

$W_{\mathrm{H}}(p)=p \frac{V-C}{2}+(1-p)(V-G)=(V-G)-p\left(\frac{V+C}{2}-G\right)$

On the other hand, the fitness of a jack $W_{\mathfrak{J}}(p)$ is represented by Equation (2) (Table 2).

$W_{J}(p)=p G+(1-p) \frac{-L}{2}=\left(\begin{array}{l}L \\ 2\end{array}\right)+p\left(G+\frac{L}{2}\right)$

\section{書式変更}

書式変更：左揃え

書式変更：フォントの色：赤

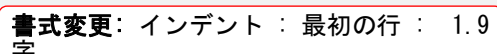

書式変更：フォント：斜体（なし） 
YOSHIMURA ET AL: DIMORPHISM IN MALE SALMON

\section{WE NEED TO SUBSTITUTE J L/2 FOR L/2 HERE AND ELSEWHERE}

Note that $W_{\perp}(p)$ is an increasing function of the hooknose proportion $p$. This is because

jacks who steal the benefits fromef $\mathrm{H}$ fight other jacks. We now examine $W_{\mathrm{H}}(p)$ and $W_{\mathrm{J}}(p)$ for

$0 \leq p \leq 1$ (Fig. 1). At $p=0, W_{\mathrm{H}}=V-G>W_{\mathrm{J}}=J-L / 2$. At $p=1$, Thus, the condition for coexistence, with

is $W_{\mathrm{H}}<W_{\mathrm{J}}$ at $p=1$. This condition, , is Equation (3) (Table 2).

$G>\frac{V-C}{2}$

When fighting between hooknoses is severe, that is, $V<C$, condition (3) is always true (Fig.

1a). This is the same result as coexistence of evolutionary strategies in the hawk-dove game. On the other hand, when fighting between hooknoses is not-se severe (i.e., is mild), that is, $V>C$, condition (3) is not always true (Fig. 1b). When $V>C$, the condition (3) incurringgiving $\operatorname{cost} C$ can be expressed as Equation (4) (Table 2).

$V>C>V-2 G$

Therefore, the fighting cost $C$ of $\mathrm{H}$ should be close to $V$, the benefit of jack $G$ should be rather
書式変更：フォント： 斜体（なし）

書式変更：フォント： 斜体（なし）

書式変更：フォント： 斜体

書式変更：フォントの色：自動

書式変更：フォント： 斜体

書式変更

書式変更：インデント： 最初の行： 1.9 
199 benefit when $\mathrm{H}$ wins, then the ESS is a pure hooknose strategy.

200

201

small, or both. From condition (4), if $2 G>V$, condition (3) automatically holds (see Fig. 1b).

Equation (5) (Table 2).

$$
p^{*}=\frac{2(V-G)+L}{V+C+L}
$$

However, the ESS becomes athe pure hooknose strategy (i.e., $p^{*=1}$ ), if Equation (6) (Table

2) holds.

$$
G<\frac{V-C}{2}
$$

When $V>C$, the slope of $W_{\mathrm{H}}(=G-(V+C) / 2)$ can be positive, if Equation (7) (Table 2) holds.
書式変更：フォントの色：赤 書式変更：フォント：斜体（なし） 書式変更：インデント：最初の行： 1.9

書式変更：左揃え, インデント：最初の 書式変更:

書式変更：左揃え

\section{書式変更}

肂式変更: 左揃え, インデント：最初の 行: 1.9 字

\begin{tabular}{l} 
書式変更：インデント：最初の行： 1.9 \\
\hline 書式変更：フォント： 斜体 \\
\hline
\end{tabular}

書式変更：左揃え, インデント：最初の 行: 1.9 字

書式変更：左揃え 
$2 G-C>V$

This means means that the fitness $W_{\mathrm{H}}$ of a hooknose is an decreasing increasing (NOT

210 i.e., $2 G+C>2 G-C>V$. Here, if $p<p *$, jack is a poor strategy, yielding lower fitness than hooknose.

When $p$ is an increasing function, the fitness of hooknose deincreases_(NOT DECREASES?) until $p$ reaches $p^{*}$. When $p>p^{*}$, since jack enjoys a higher fitness payoffalue-, the frequency of mixed ESS strategy, as long as equation (3) holds. 
YOSHIMURA ET AL: DIMORPHISM IN MALE SALMON eEquations (8a) and (8b) (Table 2).

$$
\frac{V_{N}=V \frac{B}{B+N}}{G_{N}=G \frac{B}{B+N}}
$$

CCompetition among individuals (offspring, parents or both) for limited mates or breeding sites may increase as a function of population size, $N$ (Tainaka et al. 2006), thus lowering the per capita likelihood of mating. Therefore, Consequently, the benefits of breeding, $V$ and $G$, may beare inversely related to $N$. We now examine the effect of add a negative-density effectonto ourthe density-independent hooknose-jack model.

Assume that mating values, $V$ and $G$, depend on population size $N$, according to a simple function of density, $B /(B+N)$, where $B$ is a constant. By multiplication we obtain the

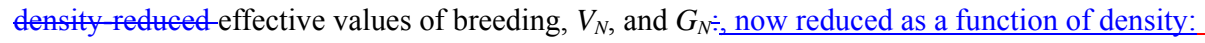

書式変更：フォント：斜体 書式変更：フォント：斜体 書式変更：フォント：斜体 


$$
W_{\mathrm{H}}(p, N)=p \frac{V_{N}-C}{2}+(1-p)\left(V_{N}-G_{N}\right)
$$

$$
W_{J}(p, N)=p G_{N}+(1-p) \frac{-L}{2}
$$

Equations (9) and (10) are similar to equations (1) and (2). Given any constant value of $N$, they are negatively (or positively) sloped, straight lines in $W-p$ space, as in the slope of equations (1) and (2).

$V^{-1}-10$ To find $p^{*}$, we examine $W_{\mathrm{H}_{-}}(p, N)$ and $W_{\mathrm{J}}(p, N)$ at $p=0$ and $p=1$. When $p=0, W_{\mathrm{H}}(0-, N)=$ $V_{N^{-}} G_{N}=V-G_{-}\left(B \_-(B+G)\right)>W_{J_{-}}(0, N)=\underline{J}-L / 2$. Therefore, the condition for coexistence of jack and hooknose is $W_{\mathrm{H}}(1, N)<W_{\mathrm{J}_{-}}(1, N)$ at $p=1$, as in the density-independent hooknose-jack model. The condition for coexistence is thenHence we get eEquation (11) (Table 2). Equation $(12)$

$$
G_{N}>\frac{V_{N}-C}{2}
$$


YOSHIMURA ET AL.: DIMORPHISM IN MALE SALMON

$$
V>C>(V-2 G) \frac{B}{B+N}
$$

(12)

This condition is identical to equation (4), except for the difference term in the right-hand side of the inequality.

Since $B$ / $(B+N)$ becomes smaller when $N$ increases, this condition is satisfied easily when

$N$ is large. Therefore, a jack can readily coexist with a hooknose, provided the population size $N$ is large. - Even if $C<(V-2 G)$, equation (11) may hold if $N>>0$, as shown inthat is, eEquation

(13) (Table 2). This means that the ESS $p *$ is a pure hooknose strategy $(\mathrm{H})$ when $N$ is small, but may shift to the mixed strategy ( $\mathrm{H}$ and $\mathrm{J})$, when the population size $N$ increases. Assuming the

書式変更：フォント：斜体 number of breeding sites is limited, the ESS strategy becomes density-dependent.

(13)

$$
V \quad 2 G>C>\left(\begin{array}{ll}
V & 2 G
\end{array}\right) \frac{B}{B+N}
$$


YOSHIMURA ET AL.: DIMORPHISM IN MALE SALMON

290 balancing game with negative frequency dependence (Figs. 1 and 2a), similar to the genetic polymorphism maintained by negatively frequency-dependent selection (e.g., Hori 1993;

\section{DISCUSSION}

Our model differs substantially from prior examples of The eurrent example is very different from those in the hawk-dove game (Maynard Smith \& Price 1973; Maynard Smith 1982; Axelrod \& Hamilton 1981) and the orangutan game (Tainaka et al. 2007) (see Fig. 2). In these games, $\mathrm{t}$ The slope of subordinates/doves is negative as well as those of hawks/dominants in these games-(Fig. 2c). By contrastHowever, in the hooknose-jack game presented here, the

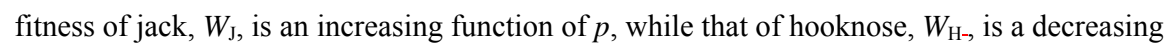
function of $p$ (Fig.; $2 \mathrm{a})$. Thuserefore, this constitutese salmen game in this condition is a true Takahashi \& Hori 1994; Fitzpatrick et al. 2007). Furthermore, the fitness of hooknose, $W_{\mathrm{H}}$, can 
benefitit is minimal. be an increasing function, too, if equation (7) holds (Fig. 2b). In this case, we canNow, if we replot Fig. $2 \mathrm{~b}$ ainst with the jack proportion defined as $q(=1-p)_{2}$ - Then, the graph becomes identical to Fig. 2c. Hower, Here, the payoff of jacks and hooknoses is reversed, in spite of the fact that jacks are poor competitors with hooknoses in direct contests over mating privileges. meaning of jack is reversed to dominant or hawk, even though jack is a sneaker that is a weaker competitor for breeding.

winning jack gains the slight fitness value $S$, where $S$ is extremelyfartastly smaller than $G$, that

is ${ }_{\triangle} V>G>>S>0$. Because the losing jack suffers a fighting cost $-L$, the average cost of fighting

between jacks is $(S-L) / 2$. Because $S$ is very close to zero (though positive), we can naturally

assume that $C \gg \gg$. Therefore, $(S-L)$ is still negative and we can putdefine $(S-L)=-L^{*}$ Hence,

substituting $L^{*}$ for $L$ changes none of the above allformulations and arguments-do not change,

if we replace $L$ into $L *$ : Thus the generality of the current results holds even if thea winner of a

contest between ing sneakers among a sneaker fight gains a minimal-benefit, because the

309
書式変更：左揃え, インデント：最初の

書式変更：フォント：斜体

書式変更：フォント：斜体

書式変更：フォント：斜体

書式変更：フォント： 斜体

書式変更：フォント： 斜体

書式変更：フォント：斜体（なし）

書式変更：フォント： 斜体

書式変更：フォント： 斜体

書式変更：フォント：斜体

書式変更：フォント： 斜体

書式変更：フォント： 斜体

書式変更：フォント： 斜体

書式変更：フォント： 斜体

書式変更：フォント： 斜体

書式変更：フォントの色：赤 
YOSHIMURA ET AL.: DIMORPHISM IN MALE SALMON jack and hooknose male mating strategies. Hooknose is the dominant strategy in terms of sperm

312 quantity, body size and controlling access to females. However, the jack life history strategy, being one year shorter, results inbenefits from lower mortality rates from natural enemies in the

314 marine habitat (Gross 1991); this assures the frequency-dependent nature of fitness tradeoffs between mating success and survival (Figs. 1 and 2). With such tradeoffs, the fitness equalities

316 of hooknose and jack are easily attained (Gross 1984). This may be why the hooknose-jack game yields a balanced polymorphism similar to those examined in other systems such as scale-eating cichlid fish (Hori 1993; Takahashi \& Hori 1994) and single-locus behavioural polymorphisms generally is similar to those of balanced polymorphisms-(Hori 1993; Takahashi \& Hori 1994; Fitzpatrick et al. 2007).

PThe previous findings suggest that sneakers and hooknoses coexist stably are

relatively stable-even in-a very small populations (Gross 1984, 1985, 1991, 1996). However, the

finite population size are often unstable, and/ordifferent from the ESS equilibrium, or both 
YOSHIMURA ET AL.: DIMORPHISM IN MALE SALMON

population sizes tend to increase the proportion of subordinate mating strategies (Tainaka et al.

2007). We expect that the sneaker frequency is unstable and high when population sizes are

small. However, oureurrent results suggest that the frequency of jack is 0 or low at a small

population size and increases as the population size increases (Fig. 2). This is the reverse of

theoretical findings for opposite to the results of finite population sizes (Riley 1979; Fogel et al.

1998; Taylor et al. 2004). Furthermore, theoretical studies shows that conditional strategies like sneakingers are stable even if the strategies have a genetic basis (Repka and Gross 1995; Gross and Repka 1998a, 1998b). The effects of population sizes may be tested empirically by

surveying the frequency and stability of the jack strategys in-a rivers of different sizes and over several years.

Previousior theoretical findings suggested that sneakers could evolve only in very small

populations, because sneaking is a conditional mating tactic due toarising as a result of

developmental disadvantages

(Fogel et al. 1998; Taylor et al. 2004). IDON'T UNDERSTAND WHY SMALL

POPULATIONS ARE NECESSARYFOR THIS? THE TITLE OF FOGELET AL.'S PAPER

SEEMS TO SUGGEST THAT ESS'S IN SMALL POPULATIONS ARE UNSTABLE. In the-

orangutan mating system, Recently, it was shown that high population densities tend to increase-
書式変更：フォントの色：赤

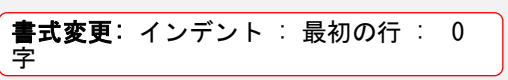

書式変更：フォントの色：赤

書式変更：フォントの色：赤 
YOSHIMURA ET AL.: DIMORPHISM IN MALE SALMON

the proportion of subordinate mating strategiess in the orangutan model (Tainaka et al. 2007).

Our modified model provides a further example in the literature with density effects is an

additionalexample-exploring the evolution and maintenance of sneaker strategies, wheren the

density of resources such as mating opportunities and breeding sites varies. density is varied,

e.g., mating opportunities and breeding sites. Our results suggest that We have refined the model

with our treatment of ddensity dependence factors, thus further promoteing the coexistence of

jack and hooknose strategies (equations (12) and (13)). WhenIf resources such as females and

breeding grounds are limited, competition for these limited resources intensifies between

dominants; consequently, subordinate strategies should become more adaptive, provided

sufficient refuges exist. since the dominants have to fight over these limited resources.For

example, suppose that there are only 10 breeding grounds or 10 females in a suitable spawning

area. If 100 hooknoses return to spawn, $90 \%$ of them (90 fish) should fail reproduction

completely. Furthermore, the winning 10 hooknoses may suffer severe fighting-related injuries.

Under such conditions, jack becomes a far superior strategy. This effect of population density is

similar teresembles that of the orangutan modelease, since subordinate strategies (jacks) become

advantageous as the population size increases (Tainaka et al. 2007). Likewise, in the colonial

acarid mite, Catoglyphus berlesei, fitness payoffs for alternative male mating strategies depend

on colony size: dominants (fighters) do better in small colonies; subordinates (non-fighters), in
書式変更：フォントの色：赤

書式変更：フォントの色：赤

書式変更：フォントの色：赤

書式変更：フォントの色：赤 
YOSHIMURA ET AL.: DIMORPHISM IN MALE SALMON large colonies (Radwan 1993). status-dependent selection in salmon yields a conditional strategy under which precocious males become jacks, and those delaying maturity become hooknoses. In fact, the sneaker life-history strategy is chosen by the fastest-growing juveniles (those with the highest status) (Gross 1996), $\underline{\text { although the precise mechanisms triggering developmental switches remain to be elucidated.- } \text { At }}$ least one author has argued the alternative tactics "fighter" and "sneaker" be regarded instead as "coercer" and "cooperator," owing toFurther, there is evidence females actually prefer the more cooperative jacks over aggressive hooknoses during spawning (Watters 2005). These facts hardly suggest that jack is an inferior life history strategy. On the contrary, the widespread occurrence of the jack strategy -supports the hypothesis that jack is an integral part of a mixed ESS strategy in salmonid fishes (Gross 1984, 1985)._ 
YOSHIMURA ET AL: DIMORPHISM IN MALE SALMON

male conditional strategies may be highly adaptive for females, in terms of spreading risk

spreading(Yoshimura \& Clark 1991; Yoshimura \& Jansen 1996). If all eggs of a female are

inseminated by one dominant male whose sperm are genetically deficient, she ends up with no

reproductive success. DNA finger-printing evidence suggests that female extra-pair matings are extremely common in many animal mating systems appearing otherwise monogamous (Burke

\& Bruford 1987; Westneat 1990; Barash \& Lipton 2001). Thus females may tacitly solicit mating opportunities fromer sneaker or subordinate males (Watters 2005), further promoting the evolution of a mixed ESS strategy.

Alternative mating tactics are known in many animal species (Gross 1982; Thornhill \&

Alcock 1983; Kodric-Brown 1986). Subordinates or sneakers have been considered the less adaptive strategy, because their payoffs-mean fitness values appearre lower than those of dominant males. However, the orangutan model (Tainaka et al. 2007) and the-eurrent model presented here suggest that the subordinates or sneakers can beare as fit as dominant males, resulting in a mixed ESS strategy. In many eases of breeding gamesmating systems, dimorphism in males may be favored under conditions of when alternative life historyontogenetic trajectories

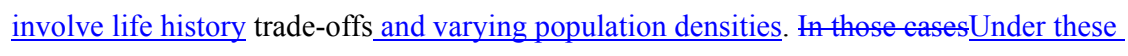

書式変更：フォントの色：赤 
YOSHIMURA ET AL.: DIMORPHISM IN MALE SALMON

400

401 conditions, both morphs gain fitness. Such evolutionary games may thus be widely prevalent not only in the matingbreeding games of dimorphic males, but in breeding systems generally.

For example, in female goldeneye ducks, population densities can play a critical role in

maintaining intraspecific brood parasitism as an alternative nesting strategy (Eadie \& Fryxell

1992). Lastly, we are only beginning to understand the magnitude of anthropogenic changes to

the environment on life history evolution, and their effects on the stability of balanced

polymorphisms in commercially important taxa such as salmonids.

\section{Acknowledgments}

We thank two anonymous referees and V. Rosenhaus for valuable comments. This work was

supported by grants-in-aid from the Ministry of Education, Culture, Sports, Science and

$\underline{\text { Technology of Japan to J. Y. and to K. T.also in the social strategies of animals and humans. }}$
書式変更：フォント：太字 㶳式変更：インデント：最初の行：0 字

書式変更：フォント：太字 
YOSHIMURA ET AL: DIMORPHISM IN MALE SALMON

\section{References}

Axelrod, R. \& Hamilton, W. D. 1981. The evolution of cooperation. Science 211: 1390-1396.

Barash, D. P. \& Lipton, J. E. 2001. The Myth of Monogamy: Fidelity and Infidelity in Animals and People. W. H. Freeman, New York.

Bulmer, M. 1994. Theoretical Evolutionary Ecology. Sunderland, MA: Sinauer Associates.

Burke, T. \& Bruford, M. W. 1987. DNA fingerprinting in birds. Nature 327: 149-152.

Eadie, J. M., \& Fryxell, J. M. 1992. Density dependence, frequency dependence, and alternative nesting strategies in goldeneyes. The American Naturalist 140: 621-641.

Fitzpatrick, M. J., Feder, E., Rowe, L. \& Sokolowski, M. B. 2007. Maintaining a behaviour polymorphism by frequency-dependent selection on a single gene. Nature 447: 210-212 (doi:10.1038/nature05764).

Fogel, D., Andrews, P. \& Fogel, D. 1998. On the instability of evolutionarily stable strategies in small populations. Eco. Mod._109:283-294.

Gross, M.R. 1982. Sneakers, satellites and parentals: polymorphic mating strategies in North American sunfishes. Zeitschrift Fur Tierpsychologie 60: 1-26.

Gross, M. R. 1984. Sunfish, salmon, and the evolution of alternative reproductive strategies and tactics in fishes. In Fish Reproduction: Strategies and Tactics (R. Wootton and G. Potts, 
YOSHIMURA ET AL: DIMORPHISM IN MALE SALMON eds.), pp. 55-75. Academic Press, London.

Gross, M. 1985. Disruptive selection for altenative life histories in salmon. Nature 313: 47-48.

Gross, M. 1991. Salmon breeding behavior and life history evolution in changing environments. Ecology 72: 1180-1186.

Gross, M. 1996. Alternative reproductive strategies and tactics: diversity within sexes. Trends in Ecology and Evolution 11: 92-98.

Gross, M. \& Repka, J. 1998. Game theory and inheritance in the conditional strategy. WHERE PUBLISHED??Gross M. R. \& Repka J. 1998a. Stability with inheritance in the conditional strategy. J. Theor. Biol. 192: 445-453.

Gross M. R. \& Repka J. 1998b. Game theory and inheritance in the conditional strategy. In: $\underline{\text { Game Theory and Animal Behavior (Eds. by L. A. Dugatkin \& H. K Reeve, eds.), pp. }}$ 168-187. Oxford: Oxford University Press.

Hori, M. 1993. Frequency-dependent natural selection in the handedness of scale-eating cichlid fish. Science. 260 (5105): 216-219.

Koseki, Y. \& Fleming, I. A. 2006. Spatio-temporal dynamics of alternative male phenotypes in coho salmon populations in response to ocean environment. J. anim. Ecol. 75: 445-455.

Krebs, J. R. \& Davies, N. B. 1987. An introduction to behavioural ecology. Oxford: Blackwell. Kodric-Brown, A. 1986. Satellites and sneakers: opportunistic male breeding tactics in pupfish 
YOSHIMURA ET AL.: DIMORPHISM IN MALE SALMON

(Cyprinodon pecoensis). Behavioral Ecology and Sociobiology 19: 425-432.

Maynard Smith, J. 1982. Evolution and the Theory of Games. Cambridge University Press,

$$
\text { Cambridge, UK. }
$$

Maynard Smith, J. \& Price, G.R. 1973. The logic of animal conflict. Nature 246, 15-18.

Radwan, J. 1993. The adaptive significance of male polymorphism in the acarid mite

\section{Catoglyphus berlesei. Behavioral Ecology and Sociobiology 33: 201-208.}

Repka, J. \& Gross M. R. 1995. The evolutionarily stable strategy under individual condition and tactic frequency. J. Theor. Biol. 176: 27-31.

Riley, J.G., 1979. Evolutionary equilibrium strategies. J. Theor. Biol. 76: 109-123.

\section{Silverstein, J.T. \& Hershberger, W.K. 1992. Precocious maturation in Coho Salmon}

(Oncorhynchus kisutch): estimation of the additive genetic variance. J. Heredity 83: 282-286.

Tainaka, K. Yoshimura, J. \& Rosenzweig, M. L. 2007. Do male orangutans play a hawk-dove game? Evolutionary Ecology Research (in press).

Tainaka, K., Yoshimura, J. \& Ushimaru, T. 2006 Stage-dependent density effect in the cell cycle of budding yeast. J. Theor. Biol. 242: 736-742.

Takahashi, S. \& Hori, M.1994. Unstable evolutionarily stable strategy and oscillation -- a model on lateral asymmetry in scale-eating cichlids, Am. Nat. 144, 1001-1020. 
YOSHIMURA ET AL.: DIMORPHISM IN MALE SALMON

Taylor, C., Fundenberg, D, Sasaki, A. \& Nowak, M. A. 2004. Evolutionary game dynamics in finite populations. Bull. Math. Biol. 66:1621-1644.

Thornhill R. \& J. Alcock. 1983. The evolution of insect mating systems. Cambridge, MA: Harvard University Press.

Watters, J. 2005. Can the alternative male tactics 'fighter' and 'sneaker'be considered 'coercer' and 'cooperator' in coho salmon? Animal Behaviour 70: 1055-1062.

Westneat, D. F. 1990. Genetic parentage in the indigo bunting: a study using DNA fingerprinting. Behavioral Ecology and Sociobiology 27: 67-76.

Yoshimura, J. \& Clark, C. W. 1991. Individual adaptations in stochastic environments. Evolutionary Ecology 5:173-192.

Yoshimura, J. \& Jansen, V. A. A. 1996. Evolution and population dynamics in stochastic environments. Researches on Population Ecology 38: 165-182. 
YOSHIMURA ET AL.: DIMORPHISM IN MALE SALMON female; $C$ : the fighting cost of a loser; $G$ : the benefit of sneaking; and $L$ : the fighting cost of a losing jack). We assume that $V>G>0$ and $C>L>0$.

486

487

488

Player

Hooknose

489

Jack

G

Opponent

490

Hooknose

Jack

$(\mathrm{V}-\mathrm{C}) / 2 \quad \mathrm{~V}-\mathrm{G}$

$-\mathrm{L} / 2$

491 
Table 2. Equations for Hooknose-Jack games in male salmon-males

$W_{\mathrm{H}}(p)=p \frac{V-C}{2}+(1-p)(V-G)=(V-G)-p\left(\frac{V+C}{2}-G\right)$

$W_{\mathrm{J}}(p)=p G+(1-p) \frac{-L}{2}=\left(-\frac{L}{2}\right)+p\left(G+\frac{L}{2}\right)$

$G>\frac{V-C}{2}$

$V>C>V-2 G$

$p^{*}=\frac{2(V-G)+L}{V+C+L}$

$G<\frac{V-C}{2}$

$2 G-C>V$

$V_{N}=V \frac{B}{B+N}$

$G_{N}=G \frac{B}{B+N}$

$W_{\mathrm{H}}(p, N)=p \frac{V_{N}-C}{2}+(1-p)\left(V_{N}-G_{N}\right)$

$W_{\mathrm{J}}(p, N)=p G_{N}+(1-p) \frac{-L}{2}$

$G_{N}>\frac{V_{N}-C}{2}$

$V>C>(V-2 G) \frac{B}{B+N}$

$V-2 G>C>(V-2 G) \frac{B}{B+N}$ 
YOSHIMURA ET AL.: DIMORPHISM IN MALE SALMON

\section{$509 \quad$ Figure legends} and subordinate, respectively.
書式変更：フォントの色：赤 hooknose is severe, that is, $V<C_{2}$; and in (b) it is mild, viz., that is $V>C$. The intersections determine a stable, mixed strategy ESS. $p *$ is the mixed ESS strategy.

Fig. 2. The slopes of the schematic payoffs $(W)$ in the breeding games between dominants and subordinates along the proportion of dominants $(p)$, where $p^{*}$ is the mixed ESS strategy. (a) the hooknose and jack model with negative frequency dependence, (b) the hooknose and jack model with dual increasing payoff functions and (c) the hawk-dove like games with dual decreasing payoff functions. $W_{\mathrm{H}}, W_{\mathrm{J}}, W_{\mathrm{D}}$ and $W_{\mathrm{S}}$ represent the fitness values of hooknose, jack, dominant 
YOSHIMURA ET AL.: DIMORPHISM IN MALE SALMON

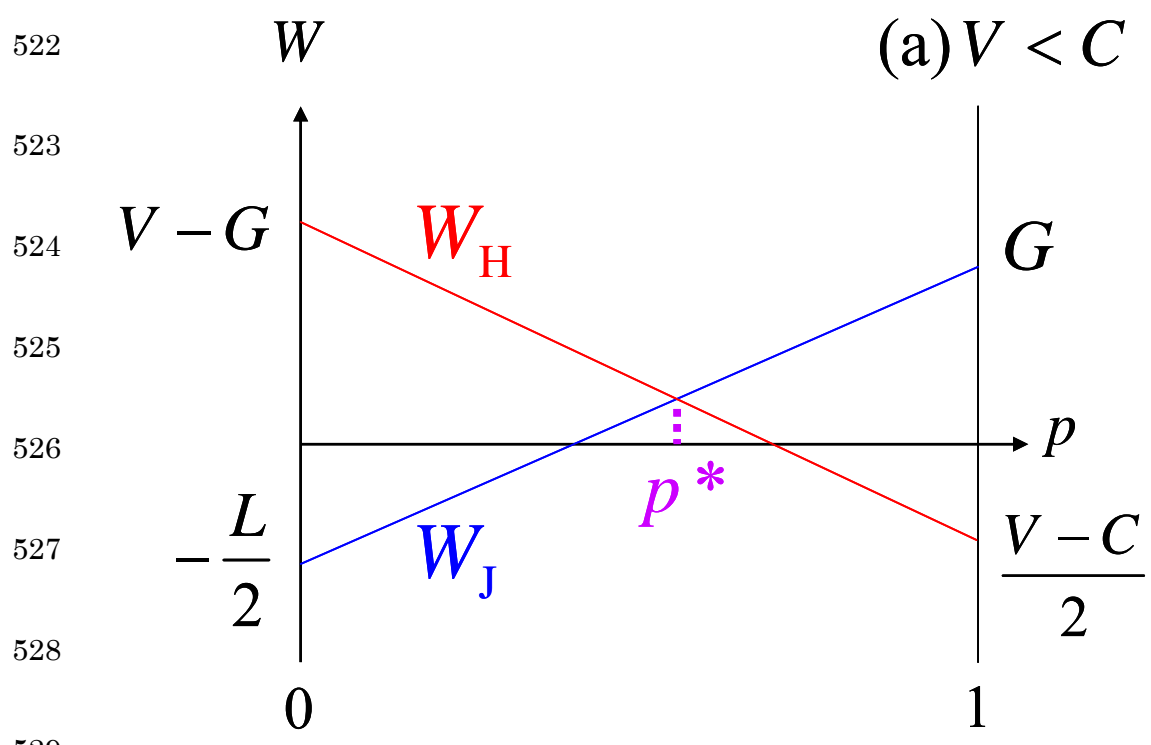

530

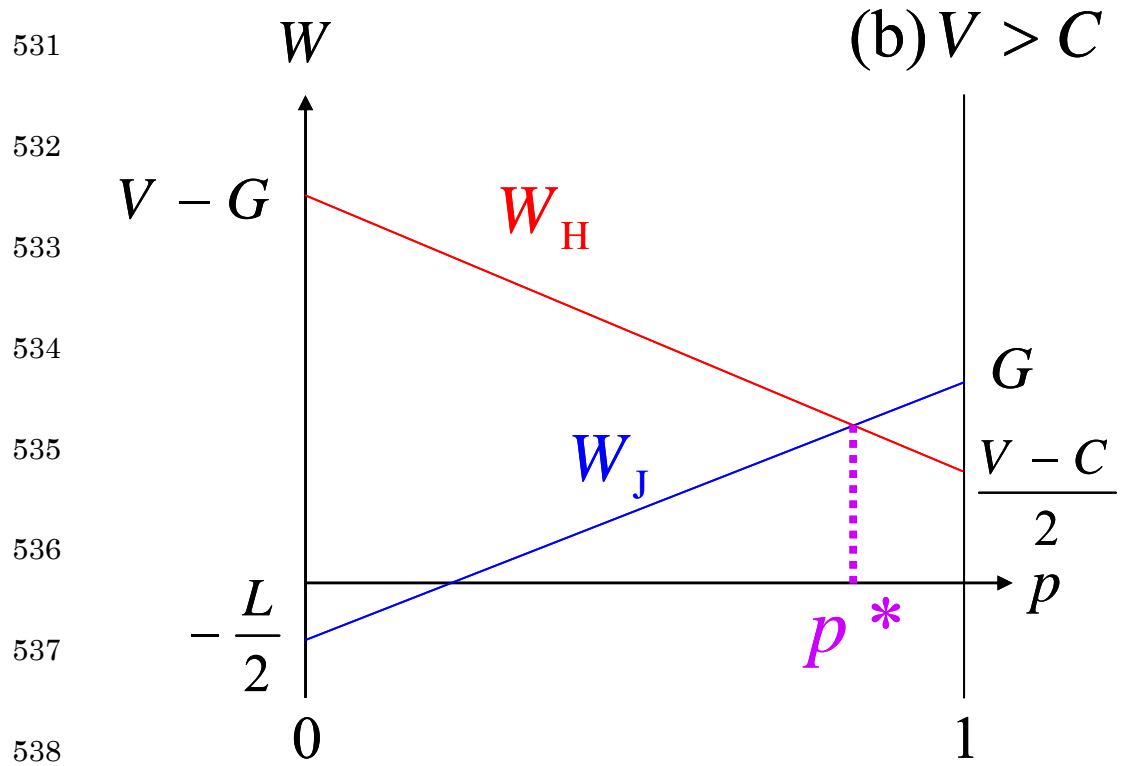

$539 \quad$ Fig. 1 
YOSHIMURA ET AL.: DIMORPHISM IN MALE SALMON

(a) $W$

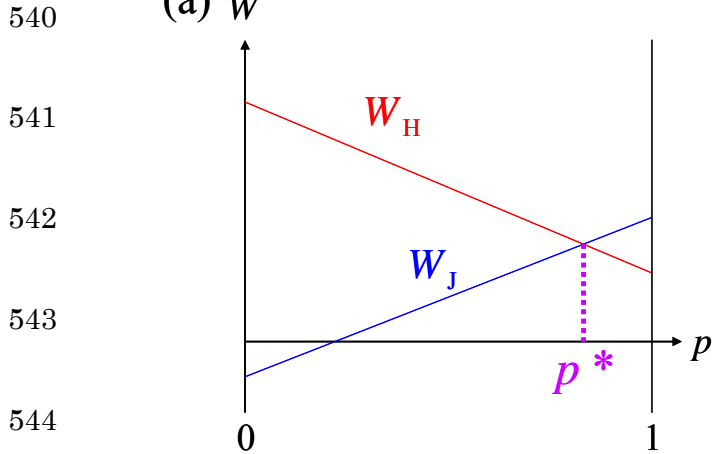

$545 \quad$ (b) $W$

546

547

548

549

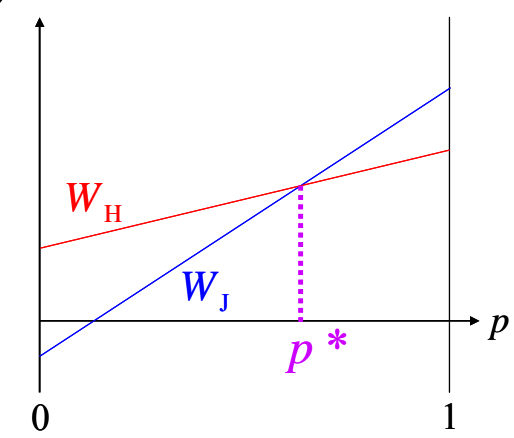

550

(c) $W$

551

552

553

554

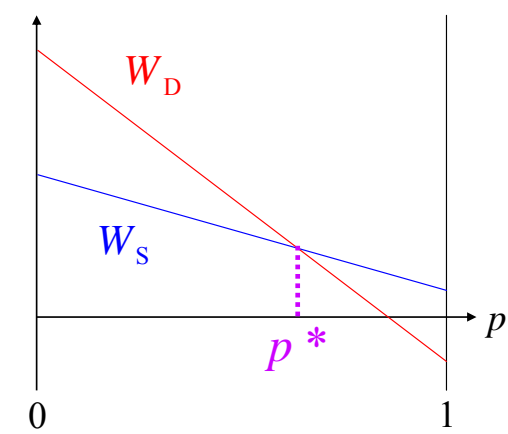

555

$556 \quad$ Fig. 2 